\title{
Tectonic Framework of China
}

$\mathrm{P}$ ROF. J. S. LEE delivered a lecture before the Geological Society on June 5 on a subject of which he is the leading authority: "The Structural Pattern of China and its Dynamic Interpretation". Since the time of Suess, it has been generally accepted that the structural framework of eastern Asia consists of a series of ares with the 'Amphitheatre of Irkusk' as their common centre. Modern researches, however, have shown that each of these arcs embraces features of different tectonic origin. Three main groups of structural elements are now recognised: (a) the Cathaysian geosynclines and their complementary geanticlines ; $(b)$ the east-west zones; and (c) the shear-forms. These seem to be fundamentally independent of each other, although they sometimes fall in line and sometimes interfere.

The Palæocathaysian geosyncline existed as an epicontinental trough, more or less parallel with the eastern border of the continent, so far back as late Pre-Cambrian time. A remnant of its borderland still remains in the coastal belt of south-eastern China. Prof. Lee traces its history to PermoCarboniferous times, when it formed the eastern extension of the Tethys, and on to the Triassic when it formed the Mesocathaysian geosyncline. It was completely filled in during the Lower Jurassic, and since then China has remained continental. Modern features arose from Jurassic-Cretaceous movements and some of them followed the old-established lines, with the result that geosynclines and geanticlines of the Cathaysian type can still be recognised. One of the present-day troughs is occupied by the Sea of Japan and the Yellow Sea; another, farther inland, stretches from the plain of Manchuria to the Central Yangtze Basin and is named the Neocathaysian geosyncline.

The east-west zones, tabulated below, exhibit a rhythmic orogeny that is one of the most striking tectonic phenomena of eastern Asia. It will be noted that the interval between the ranges is $8^{\circ}$ of latitude in every case.
The third group of features includes various shear-forms, of which three types predominate. One of these forms consists of a series of nearly parallel folds trending north-east or north-west and is known as the $\xi$ type. These are commonly traversed by faults roughly perpendicular to the axes. Another consists of a frontal are with a radial backbone, somewhat after the fashion of a bow and arrow, and is called the $\varepsilon$ type. The third is a bundle of folds eurving round an old massif or mountain mass and is designated the $\eta$ type.

\begin{tabular}{|l|c|c|c|c|}
\hline \multirow{3}{*}{ Orogenic Epochs } & \multicolumn{4}{|c|}{ Ranges and their latitudes } \\
\cline { 2 - 5 } & $\begin{array}{c}\text { Tannu- } \\
\text { Kentai } \\
49^{\circ}-50^{\circ} \mathrm{N}\end{array}$ & $\begin{array}{c}\text { Inshan } \\
41^{\circ}-42^{\circ} \mathrm{N}\end{array}$ & $\begin{array}{c}\text { Tsingling } \\
33^{\circ}-34^{\circ} \mathrm{N}\end{array}$ & $\begin{array}{c}\text { Nanling } \\
25^{\circ}-26^{\circ} \mathrm{N}\end{array}$ \\
\hline Tertiary & - & $\times$ & $?$ & $?$ \\
Jurassic-Cretaceous & $\times$ & $\times$ & $\times$ & $\times$ \\
Hercynian & $?$ & $?$ & $\times$ & $\times$ \\
Caledonian & $\times$ & $\frac{?}{\times}$ & $?$ & $\times$ \\
Pre-Sinian & $\times$ & $\times$ & $\times$ & $\times$ \\
\hline
\end{tabular}

Consideration of the mechanics, supported by experimental reproductions, leads Prof. Lee to the belief that the shear-forms imply horizontal shearing movements of the upper layer of the continental mass, directed on one hand against the Tibetan massif or the shattered ends of the east-and-west ranges, and on the other against the border of the continent. The other features also suggest southerly movement of the continental mass, and it is suggested that the driving force might have been supplied by an increased speed of rotation of the earth due, for example, to concentration of mass in the interior or to bodily contraction of the earth as a whole. An attempt is made to test the hypothesis by the distribution in time and place of the marine transgressions of the past, some twenty-one of which (major cycles) are recognisable since the beginning of the Cambrian. For a more extensive summary of the lecture, reference should be made to $A b s$. Proc. Geol. Soc. London, No. 1298, June 17, 1935.

\section{Return of Mineral Elements to the Soil by Plants}

$\mathbf{I}^{\mathrm{T}}$ is not generally known that plants can return to the soil at some stage of their growth, either after the first burst of vegetative activity or after maturation of the fruits, certain of the more important nutrient elements which they have absorbed.

Until recently the evidence was meagre, but a series of papers published in Bucharest by Prof. Deleanu and his colleagues ${ }^{1-3}$ recording the result of investigations into the function of mineral elements in the life of the plant, has added considerably to our knowledge of this phenomenon.

In 1908 Prof. Deleanu himself ${ }^{4}$ found that there was a reversal of the process of absorption of soil constituents, called by him 'negative migration', which occurred in oat plants after they had reached maximum growth, the loss being 64 per cent of the ash elements and 47 per cent of nitrogen. In 1919 J. S. Burd ${ }^{5}$ recorded that with barley grown on two different soils, the initial progressively increasing rate of absorption of the soil constituents during the early stages of vegetative development was followed by a period of actual loss, coincident with the development of the heads, and succeeded by renewed absorption at a later period. The absorp. tion and loss were most marked in the elements potassium and nitrogen. In maize the rate of absorption decreased considerably prior to head formation, though no actual loss of soil constituents was found ${ }^{6}$. Plants such as the potato, on the other hand, show no such striking ehange in the rate of absorption. 
In the recent Bucharest investigations, V. G. Bossie $^{2}$, working with wheat, shows that the cycle of absorption and migration is somewhat similar to that of barley, differing only in details. The life period of some seventy days in wheat can be divided into three phases: (1) vegetative, which reaches its maximum by the twenty-sixth day; (2) fruiting, which commences about the thirty-first day and culminates about the sixty-fifth day, and (3) postmaturity. Absorption of all mineral elements in the aerial portions as a whole was rapid and very considerable during phase (1); thereafter the rate of absorption of phosphorus, nitrogen and magnesium was markedly decreased, but none of these was lost, whereas in the case of potassium and calcium actual loss occurred after the first twenty-six days; silica, which amounts to nearly half the total ash, continued to be absorbed more or less regularly until maturity, when some loss of all elements occurred. The amount of the loss was most marked in the case of potassium and calcium, as negative migration of these had started early, but the loss in all other cases was less than 20 per cent. What is happening is that during the stage (2) the developing ear is drawing its supplies of nutrients from the leafy stems, silica only being absorbed directly from the soil; the supply of nitrogen, phosphorus and magnesium is inadequate in the leaves and so a further slight absorption of these elements from the soil takes place; potassium and calcium, however, are in excess of the amount required by the ear, and so can be returned to the soil.

The phenomenon of negative migration occurs in other groups of plants. In tobacco, for example, not only does loss of soil constituents occur when the main stem has reached maturity, but it may also be succeeded by re-absorption and further negative migration corresponding with the development of axillary shoots ${ }^{3}$.

It seems obvious, therefore, that the reason for the changes in the rate of absorption by the plant must be sought in the metabolic state of the tissues, and that when actual loss occurs it is probably due to the interaction of the factors causing the meta. bolic changes and the factors of the soil environment affecting absorption. In this respect it is well to mention that Burd ${ }^{5}$ found that the losses occurred in oats when the constituents of the water extracts of the soil were at or approaching their minima and when the same constituents were moving from the leaves to the ear.

It has been suggested that the elements migrating from the aerial organs are accumulated by the roots. In the paper by Bossie, however, details of the analyses of roots have been included, and bearing in mind the difficulties attending collection of these organs from the soil, the resuits show that this cannot be the case; for example, from the twentysixth day to the thirty-fifth day, the aerial organs of a hundred wheat plants lost $0.187 \mathrm{gm}$. of potassium, whereas the roots only accumulated $0.001 \mathrm{gm}$. in the same time; the other $0.186 \mathrm{gm}$. must therefore have been returned to the soil.

\section{N. L. Penston.}

${ }^{1}$ Deleanu, N. T., and Bordeianu, C., Acad. Roma. Mem. Sect. Stiint. Ser. 111, Tom. ix, Mem. 10 (1934), "Studiu asupra rolului si functiunil substantelor minerale si organice in viata plantei", No. 11.

${ }^{2}$ Bossie, V. G., Lab. de Chim. Anal. Facultatea de Farmacie, ibid., No. iv ; 1934 .

${ }^{3}$ Vladescu, I. D., Lab. de Chimie. Anal. Universitatea din Bucuresti, ibid., No. $\mathbf{2} ; 1934$

- Deleanu, N. T., Trav. de. l'Institut de Bot. Geneve, 1908.

s Burd, J. S., J. Agric. Res., 18; 1919.

- Jones and Huston, Ind. Expt. Sta. Bull., 175 ; 1914.

\section{Third Imperial Mycological Conference}

$\mathrm{I}^{\mathrm{N}}$ $\mathrm{N}$ spite of financial stringency, which has cramped the activities of many scientific institutions of recent years, the Imperial Mycological Institute organised a very successful Conference at the Imperial College of Science and Technology in September 1934. Invitations were conveyed to overseas Governments of the British Empire, to certain Government Departments of the United Kingdom, and to the staffs of agricultural and horticultural research stations, university departments, to individual mycologists, and to the representatives of certain firms interested in the manufacture of fungicides. A report of the activities of this Conference has recently appeared (Imp. Mycol. Inst., Kew, Surrey, pp. 32, 2s. net).

Sir Charles Howell Thomas opened the proceedings of the Conference on September 17. In the course of his speech of welcome, he referred to the change in administrative control of the Institute, and praised the work of Lord Buxton in fostering the efficient work of the Institutes of Mycology and Entomology before they were taken over by the Executive Council of the Imperial Agricultural Bureaux. The future finance of the Institute of Mycology gives cause for concern, and was the subject of deliberation by a special sub-committee. It was recommended that representations be made to the various Governments supporting the Institute for restored or increased financial aid.

The Director (Dr. E. J. Butler), in reviewing the work of the Institute, showed that enormous financial losses are sustained as a result of fungal attack, and stressed the importance of disease surveys in demonstrating such loss. He also discussed the publication of the Institute's periodical Review of Applied Mycology.

The deliberations of the Conference naturally covered a wide field. Administrative measures against plant diseases, methods of standardisation of insecticides and fungicides, virus diseases, control methods for small cultivators, foot-rots of cereals, breeding and selection for immunity against disease, and several papers on diseases of particular crops, formed the main topies.

One important activity of the Conference lay in the drafting of a health certificate to be given to consignments of plants made within the Empire. This is not designed to replace any legislation or quarantine regulations, and carries nothing but a hallmark of freedom from disease. If this practice is adopted extensively, it should mark a very considerable advance in the control of fungus diseases. 